Stanisława Trebunia-Staszel

ORCID: https://orcid.org/0000-0001-8694-5934

Instytut Etnologii i Antropologii Kulturowej

Uniwersytet Jagielloński

\title{
Muzeum Tatrzańskie jako laboratorium dziedzictwa. Część II
}

\author{
The Tatra Museum as a laboratory of heritage. \\ Part II
}

\begin{abstract}
At the end of the $19^{\text {th }}$ century, in a small mountain village of Zakopane in the Podhale region, Polish intellectuals established the Tatra Museum - an institution which soon exceeded its provincial character and played an important role in the process of creating the popular image of the Podhale region with a special regard to its significance to Polish national heritage.

In the present article, the author attempts to describe and analyse the museum practices adopted by the Tatra Museum through the years to follow the process of constructing the different visions of the Podhale region and the respective concepts of cultural heritage.
\end{abstract}

Key words: The Tatra Museum, Podhale region, museum practices, cultural heritage, ethnicity, identity.

Pod koniec XIX wieku w niewielkiej górskiej miejscowości Zakopane polscy intelektualiści założyli Muzeum Tatrzańskie - placówkę, która z czasem urosła do rangi muzeum o znaczeniu ogólnonarodowym, odgrywając istotną rolę w kształtowaniu wizerunku Tatr i góralszczyzny w polskiej kulturze. W prezentowanym artykule autorka stara się prześledzić stosowane w Muzeum Tatrzańskim praktyki muzealne i koncepcje gromadzenia, przechowywania i eksponowania zbiorów, chcąc tym samym uchwycić wytwarzane tu w różnych okresach czasu odmienne wizje góralszczyzny i odpowiadające im koncepcje dziedzictwa kulturowego.

Słowa kluczowe: Muzeum Tatrzańskie, Podhale, praktyki muzealne, dziedzictwo kulturowe, etniczność, tożsamość.

Odebrano / Received: 31.01.2019

Zaakceptowano / Accepted: 27.08.2019 
W poprzednim numerze „Journal of Urban Ethnology” (2018) ukazała się pierwsza część prezentowanego artykułu. Zarysowane zostały w niej główne zagadnienia i problemy wyznaczające oś zasadniczych rozważań. Odwołując się do teorii z zakresu praktyk muzealnych ${ }^{1}$, a także nowej koncepcji dziedzictwa ${ }^{2}$ przyjęłam, że muzeum jako instytucja deponująca pamięć o przeszłości, a także prezentująca i kreująca w ekspozycyjnych aranżacjach określone wizje rzeczywistości ${ }^{3}$ może być też swoistym laboratorium dziedzictwa. W tak zarysowanej perspektywie starałam się prześledzić pierwsze półwiecze działalności Muzeum Tatrzańskiego (MT), zwracając uwagę przede wszystkim na stosowane w nim praktyki muzealne, by tym samym uchwycić wytwarzane w zakopiańskiej placówce wizje góralszczyzny i odpowiadające im koncepcje dziedzictwa. Poniżej omówię losy placówki w okresie hitlerowskiej okupacji.

\section{Zakopiańskie Muzeum ${ }^{4}$ w czasie niemieckiej okupacji. Zawiłe historie.}

Dotychczasowe publikacje poświęcone dziejom zakopiańskiego Muzeum przynoszą bardzo ogólną i zdawkową wiedzę na temat okupacyjnych losów tej placówki. Najwięcej informacji dotyczących tego okresu zawiera sprawozdanie z 1946 roku sporządzone przez ówczesnego dyrektora MT Juliusza Zborowskiego, na polecenie Zarządu Związku Muzeów w Polsce . Autor wymienił w nim główne problemy, z jakimi musiało się zmagać polskie kierownictwo pod zarządem niemieckich władz okupacyjnych. Do najważniejszych zaliczył ochronę i utrzymanie zbiorów oraz zabezpieczenie samego budynku. W dokumencie wspominał też o niemieckich planach reorganizacji Muzeum, próbach usunięcia polskiego personelu oraz licznych wizytach tzw. „Aufseherów” wysyłanych przez „różne urzędy niemieckie”. Przedstawiając powyższe kwestie Zborowski

1 W swych rozważaniach dotyczących działań muzealnych zwróciłam uwagę przede wszystkim na aspekt kolekcjonowania i eksponowania zbiorów, a także politykę określania tożsamości i wartości. Nawiązując do istniejących już opracowań, przyjęłam, że muzeum pełniąc rozliczne funkcje poznawcze, edukacyjne, estetyczne i rozrywkowe jest instytucją, gdzie kreuje się określone wizje rzeczywistości. W takim ujęciu zdeponowane zbiory stanowią podstawowe tworzywo do działań symbolicznych, intelektualnych i artystycznych, które zazwyczaj znajdują swą zmaterializowaną reprezentację w ekspozycji muzealnej. Zob. Wieczorkiewicz 1996, s. 37-38; Folga-Januszewska 2008, s. 202; Żygulski 1982, s. 167.

2 Zob. Kowalski 2013. W przywołanym opracowaniu autor uwypuklając różnice między tradycyjnym rozumieniem dziedzictwa, a jego współczesnym ujęciem (zagarniającym, opisującym i organizującym coraz to nowe obszary rzeczywistości), zaznacza, że nowe dziedzictwo to nie tylko świeże spojrzenie na przeszłość, lecz także dokonująca się selekcja przeszłości z perspektywy aktualnych potrzeb, dążeń, oczekiwań i dominujących wartości. W takim ujęciu dziedzictwo jest więc społeczno-kulturowym konstruktem odwołującym się do lokalnej, regionalnej, narodowej bądź ogólnoludzkiej przeszłości, jest aktem wyboru, interpretacji lub reinterpretacji, który ma służyć teraźniejszości - zarówno w sferze polityki, gospodarki, kultury czy też edukacji. Kowalski, s. 5-20.

3 Zob. Trebunia-Staszel 2018, s. 217-231.

4 „Muzeum” zapisane w tekście dużą literą oznaczać będzie Muzeum Tatrzańskie. Taki zabieg pozwoli uniknąć zbędnych powtórzeń.

5 Zborowski 2001, s. 258-262.

6 Zborowski, s. 259 
nie podał jednak żadnych nazwisk stosując eufemizmy typu: „Aufseher”, ,jeden z urzędników” czy też „okupant”. Nie poruszył też kwestii działalności hitlerowskich funkcjonariuszy w Muzeum, ani tematu badań rasowo-ludoznawczych prowadzonych na Podhalu w latach 1940-42 przez pracowników Sektion Rassen- und Volkstumsforschung $(\mathrm{SRV})^{7}$ - jednej z sekcji nazistowskiego Institut für Deutsche Ostarbeit (IDO) założonego w Krakowie przez władze okupacyjne ${ }^{8}$. Czytając po latach raport Zborowskiego, analizując jego zawartość z perspektywy dostępnej dziś wiedzy można przypuszczać, że oszczędny ton i lakoniczny charakter przedstawionego dokumentu wynikał $\mathrm{z}$ obaw autora, że przywołując tego typu fakty zostanie posądzony o kolaborację. Stąd w sprawozdaniu zaznaczył jedynie, że w przyszłości „może trzeba będzie coś więcej napisać”" Jednak nie podjął już tego wątku w swych późniejszych pracach. Natomiast ujawnione $\mathrm{w}$ ostatnich latach nowe materiały archiwalne dotyczące wspomnianej powyżej Sektion Rassen- und Volkstumsforschung ${ }^{10}$, jak i dokumenty pozyskane w czasie kwerend przeprowadzonych w Archiwum Akt Nowych w Warszawie (AAN) ${ }^{11}$ pozwoliły uzupełnić znacząco sprawozdanie Zborowskiego, rzucając nowe światło na temat niemieckich działań w Muzeum ${ }^{12}$. Pokazały też, że przynajmniej do roku 1942 władze administracyjne Generalnego Gubernatorstwa (GG) wykazywały duże zainteresowanie podhalańską placówką. Ta szczególna „troska” wynikała z roli jaką miało pełnić Muzeum w tym zastrzeżonym dla Niemców podtatrzańskim mieście ${ }^{13}$. Przypomnijmy hitlerowcy plano-

\footnotetext{
${ }^{7}$ Sekcja Rasowo-Ludoznawcza, w innych tłumaczeniach Sekcja Badań Rasy i Ludoznawstwa.

${ }^{8}$ Institut für Deutsche Ostarbeit (Instytut na Rzecz Niemieckiej Pracy na Wschodzie, w innych tłumaczeniach Instytut Niemieckich Prac na Wschodzie, Instytut Niemieckiej Pracy Wschodniej) założony został przez władze okupacyjne w Krakowie w 1940 roku. W skład Instytutu wchodziło jedenaście sekcji badawczych, w tym wspomniana Sektion Rassen- und Volkstumsforschung (SRV), której pracownicy głównie antropolodzy i etnolodzy - prowadzili intensywne badania rasowe i etnograficzne w wybranych miejscowościach Generalnego Gubernatorstwa. Jednym z regionów objętych badaniami było Podhale. Działalność wspomnianej Sekcji została omówiona w zbiorowym tomie pt. Antropologia i etnologia w czasie wojny. Dziatalność Sektion Rassen- und Volkstumsforschung Institut für Deutsche Ostarbeit, Krakau 19401944 w świetle nowych materiatów źródtowych, Maj M. (red.), 2015. Zob. też Rybicka 2002.

${ }^{9}$ Zborowski 2001, s. 260.

${ }^{10}$ Zgromadzone przez Sekcję materiały po zakończeniu wojny zostały przetransportowane do Stanów Zjednoczonych i zdeponowane w National Anthropological Archives w Smithsonian Institution w Waszyngtonie. W 2008 roku strona amerykańska przekazała kolekcję SRV do Archiwum Uniwersytetu Jagiellońskiego. Zob. Kolekcja Sektion Rassen-und Volkstumsforschung IDO, Archiwum UJ, Box 1-83. Oprócz waszyngtońskiego zbioru w Archiwum UJ znajdują się także inne materiały IDO, które nie zostały wywiezione przez Niemców z Krakowa. Określane są jako tzw. Stare IDO.

${ }^{11}$ Omawiane materiały to zbiór pism urzędowych w sprawie Muzeum Tatrzańskiego. Dokumentacja znajduje się w Archiwum Akt Nowych w Warszawie. Jest częścią Zespołu Akt Rządu Generalnego Gubernatorstwa 1939-1945 (ZARzGG), nr zespołu 111. Kwerendy archiwalne w AAN prowadzone były przez autorkę tekstu oraz dr Małgorzatę Maj.

${ }^{12}$ Szerzej na ten temat piszę w: Trebunia-Staszel 2016.

${ }^{13}$ Zakopane i jego najbliższe okolice na mocy zarządzenia z 23 lutego 1940 roku uznane zostały za strefę zamkniętą. Mieszkańcy wydzielonej strefy, którzy osiedlili się tam po 1 stycznia 1930 r., zostali zewiden-
} 
wali stworzyć w Zakopanem ośrodek rekreacyjny dla żołnierzy Wehrmachtu, inwalidów wojennych oraz nazistowskich dygnitarzy, a Muzeum stanowić miało jedną z atrakcji turystycznych dla niemieckich "gości”. Poza tym widziano w placówce narzędzie propagandowe. „Niezamykaniem muzeum” jak odnotował J. Zborowski, władze niemieckie „chciały podkreślić ważność góralszczyzny, opiekę nad góralami, ich ludową kulturą i wmówić odrębność tej kultury od ogólnopolskiej"14.

Od 1940 roku Muzeum Tatrzańskie podlegało Abteilung Kultur und Unterricht beim Chef des Distrikts Krakau (Wydział Kultury i Oświaty przy Szefie Dystryktu Krakowskiego ${ }^{15}$. Na polecenie kierownika tegoż Wydziału już w maju 1940 roku w zakopiańskiej placówce przeprowadzono inspekcję. Jej wyniki zawarte zostały w raporcie sporządzonym przez austriackiego etnologa dr Antona Plügla, który zatrudniony był we wspomnianej agendzie jako referent ds. muzealnictwa, a rok później podjął pracę w Institut für Deutsche Ostarbeit ${ }^{16}$. Warto odnotować kilka zdań o tym badaczu, gdyż pozostawił obszerny i zarazem budzący wiele kontrowersji dorobek $z$ badań na Podhalu. Plügel pojawił się w okupowanej Polsce na początku 1940. Był młodym, ambitnym, wszechstronnie wykształconym antropologiem i jednocześnie zagorzałym aktywistą $\mathrm{NSDAP}^{17}$. O politycznym zaangażowaniu Plügla wymownie świadczy przygotowany przez niego propagandowy tekst zamieszczony w organie NSDAP „Das Vorfeld” w 1941 roku. Podkreślał w nim między innymi kulturową i rasową niższość narodu polskiego, pisząc, że „rasa wschodnia nie stworzyła żadnej własnej twórczej kultury” ${ }^{18}$. Niemniej warto zaznaczyć, że w późniejszych opracowaniach na temat Podhala, tonował swe nachalne, pełne pogardy sądy na temat „rasy wschodniej” i Polaków ${ }^{19}$. Można przypuszczać, że bliższe poznanie kultury góralskiej, bezpośredni kontakt z mieszkańcami podhalańskich wsi w czasie badań terenowych, a także znajomość z przedstawicielami zakopiańskiej inteligencji, przede wszystkim zaś z J. Zborowskim mogły wpłynąć na zmianę stosunku Plügla do górali, co oczywiście w żaden sposób nie usprawiedliwia jego politycznego zaangażowania.

Począwszy od swej pierwszej wizyty w Muzeum w 1940 roku Plügel często odwiedzał tę instytucję. $Z$ uznaniem wyrażał się o zgromadzonych tu obiektach oraz zasobach bibliotecznych. Dla celów badawczych sporządził obszerną dokumentację tatrzańskich

cjonowani, a następnie zmuszeni do wyjazdu. Gąsiorowski 2010, s. 20-23.

${ }^{14}$ Zborowski 2001, s. 258

${ }^{15}$ W ramach wspomnianego Wydziału istniała Gruppe Kunst, Museen und Sammlungen (Sekcja Sztuka, Muzea i Zbiory) z odrębnym referatem Musealwesen (referat ds. Muzealnictwa).

${ }^{16} \mathrm{Na}$ temat działalności naukowej i politycznej A. Plügla przed przybyciem do Polski piszą między innymi: Michel 2000, s. 149-166 oraz Gottschall 2015, s. 95-102.

${ }^{17}$ Michel 2000, s. 154.

${ }^{18}$ Plügel 1941a, s. 14.

${ }^{19}$ Mam na myśli obszerne studium przygotowane przez Plügla na temat historii i kultury Podhala pt. Die podhalanischen Góralen im südlichsten Teil des Kreises Neumark. Wspomniane opracowanie zostało opublikowane w trzech częściach na łamach wydanego przez IDO periodyku "Die Burg” w latach 1941-42. 
muzealiów, którą wykorzystał w swym studium poświęconym góralszczyźnie ${ }^{20}$. Cenił także profesjonalizm Zborowskiego. Często korzystał z jego wiedzy i konsultacji ${ }^{21}$.

J. Zborowski w czasie wojny nie został odsunięty od kierowania Muzeum, niemniej jak sam zaznaczył w sprawozdaniu, władze okupacyjne zakładały przekazanie kierownictwa w ręce niemieckie. Potwierdzają to także materiały ze zbioru SRV IDO oraz pisma administracji rządowej GG zdeponowane w AAN. Z tych ostatnich wynika, że po odejściu inspektora szkolnictwa Heinza Petera, który do początku 1941 roku sprawował nadzór nad Muzeum ${ }^{22}$, podjęto działania w zakresie powołania nowego dyrektora. Głównymi kandydatami byli ludoznawca Morawetz (w dokumentacji brak imienia przyp. STS) oraz Hermann Mentz, nauczyciel szkoły średniej w Zakopanem. Zachowane pisma wskazują, że podjęcie decyzji w tej sprawie wywołało wśród niemieckich urzędników spór kompetencyjny, który skądinąd wpłynął korzystnie na zachowanie stanowiska przez Zborowskiego ${ }^{23}$. H. Mentz usilnie zabiegał o objęcie funkcji dyrektora, licząc na wsparcie ze strony SS w osobie dr Richarda Albrechta zatrudnionego jako referent w Abteilung Wissenschaft, Erziehung und Volksbildung przy rządzie GG (ówczesna nazwa Wydziału, tj. marzec 1941 rok ${ }^{24}$. Jednak, jak sugeruje treść korespondencji inny urzędnik tegoż Wydziału dr Karl Nowotny ${ }^{25}$ nie był skłonny zaakceptować tej kandydatury $^{26}$, sprzyjając raczej polskiemu dyrektorowi. W ostatecznym rozrachunku ani Morawetz ani Mentz nie otrzymali posady. Zanim jednak zrezygnowano z kandydatury Mentza zgodnie z poleceniem władz Wydziału przygotował on plan dotyczący reorganizacji ekspozycji i zasad funkcjonowania Tatra-Muzeum. Przyjrzyjmy się zatem przywołanym powyżej niemieckim raportom ${ }^{27}$.

${ }^{20}$ Plügel 1941b, s. 54-66; Plügel 1942a, s. 94-159; Plügel 1942b, s. 236-257.

${ }^{21} \mathrm{Na}$ temat działalności badawczej A. Plügla na Podhalu podczas niemieckiej okupacji zob. Maj, Trebunia-Staszel 2015, s. 115-127.

${ }^{22}$ S. Trebunia-Staszel 2016, s. 271-291

${ }^{23}$ Zaistniałe między niemieckimi urzędnikami nieporozumienia skomentował w swym sprawozdaniu J. Zborowski odnotowując, że ułatwiały mu one „niewykonywanie poleceń Abteilungu”. Zborowski 2001, s. 259.

${ }^{24}$ Abteilung Kultur und Unterricht przemianowany został w 1940 roku na Abteilung Wissenschaft, Erziehung und Volksbildung. 1 kwietnia 1941 roku Wydział ten uzyskał ostateczną nazwę Hauptabteilung Wissneschaft und Unterricht.

${ }^{25}$ Dr Karl A. Nowotny w czasie okupacji pełnił także nadzór nad Muzeum Archeologicznym w Krakowie. Warto odnotować, że polscy pracownicy krakowskiego muzeum wspominali Nowotnego jako życzliwego Polakom urzędnika. Pozytywnie o Nowotnym wyrażali się między innymi Rudolf Jamka oraz Anna Kowalska-Lewicka. Zob. R. Jamka 1964, s. 208-221 oraz Kowalska-Lewicka 2004, Muzeum Archeologiczne $P A U$-czas okupacji (luźne wspomnienia).

${ }^{26}$ Świadczyć może o tym skonstruowane w formie zażalenia pismo Mentza skierowane do referenta Wydziału R. Albrechta. Mentz skarży się w nim, że dr Nowotny w sprawach Muzeum kontaktuje się z „administratorem Zborowskim", ignorując całkowicie jego osobę. Pismo z dn. 29 maja 1941, AAN, sygn. $111 / 1454$.

${ }^{27}$ Jak już zaznaczyłam, szczegółową analizę raportów A. Plügla i H. Mentza przedstawiłam w: Trebunia-Staszel 2016. W prezentowanych rozważaniach odwołuję się do wspomnianego tekstu, koncentrując się 
A. Plügel opracowany przez siebie raport Planung für die Neuaufstellung des Tatra-Museums in Zakopane (Plan nowej ekspozycji Muzeum Tatrzańskiego w Zakopanem) opatrzony datą 9 maja 1940 roku $^{28}$ przedstawił stojącemu na czele Abteilung Kultur und Unterricht dr Adolfowi Watzke. Przygotowując dokument Plügel uwzględnił w nim wytyczne z przedwojennego planu rozwoju Muzeum ${ }^{29}$. Akceptując polski projekt zawarł jednak w przedłożonym raporcie szereg własnych uwag i sugestii.

Główne uwagi krytyczne Plügla przedstawione w omawianym dokumencie dotyczyły słabo rozwiniętej działalności Muzeum w miejscowym środowisku, nade wszystko zaś jego znikomej roli w procesie kształtowania i wzmacniania tożsamości etnicznej. Uważał on,że Muzeum nie pełniło odpowiedniej roli w życiu górali jako Heimatmuseum (Muzeum ojczyźniane). Dlatego też akcentował nie tylko konieczność uwypuklenia całej różnorodności kultury góralskiej, ale nade wszystko wykazanie jej odrębności względem polskiej grupy narodowej. Należy zaznaczyć, że Plügel w odniesieniu do górali podhalańskich zarówno w omawianym raporcie, jak i w innych tekstach używał określenia „narodowość góralska”, co odpowiadało polityce niemieckich władz okupacyjnych w stosunku do grup karpackich zamieszkujących $\mathrm{GG}^{30}$. W swym raporcie podkreślał, że Muzeum Tatrzańskie nie pokazywało rzeczywistego obrazu kultury górali i „wartości narodowości góralskiej” . Stąd postulował np. zobrazowanie „specyficznych cech języka góralskiego” poprzez krótkie „próbki tekstowe” i uwydatnienie jego odmienności w stosunku do języka polskiego. Wskazywał potrzebę wydania przewodnika muzealnego nie tylko w języku niemieckim, ale i góralskim. Uważał, że wysiłki badawcze i działania wystawiennicze powinny skoncentrować się przede wszystkim na ekspozycji ludoznawczej. Twierdził, że jest ona ważniejsza od wystawy krajoznawczo-fizjograficzna, gdyż w sugestywny sposób „oddaje obszerny i gruntowny obraz życia góralskiego i góralskiej kultury”. W zakończeniu sugerował, aby rozbudować całą wystawę o treści z zakresu antropologii fizycznej pisząc, że ekspozycję powinien zamykać „krótki rasoznawczy przegląd górali i Podhala" ${ }^{1}$.

jednak przede wszystkim na tych wątkach, które dotyczyły ideologicznych przekształceń profilu Muzeum Tatrzańskiego.

${ }^{28}$ Planung für die Neuaufstellung des Tatra-Museums in Zakopane. Archiwum UJ, SRV IDO, Box 01/04/02.

${ }^{29} \mathrm{~W}$ cytowanym już sprawozdaniu Zborowski pisze, iż jeden z urzędników Wydziału „mający zrozumienie dla muzeologii i traktujący tzw. „Goralenfrage” (!) jako nonsens” zapoznawszy się z przedwojennymi planami rozwoju Muzeum zaakceptował je bez zmian”. Zborowski 2001, s. 259.

${ }^{30}$ Polityka narodowościowa generalnego gubernatora Hansa Franka zgodnie z wolą Führera kierowała się zasadą „dziel i rządź” i zmierzała do podkreślenia wszelkich możliwych odrębności grup etnicznych i regionalnych zamieszkujących GG. W czasie zebrania 3 maja 1940 roku polecał Frank swoim współpracownikom: „W postępowaniu ze wszystkimi grupami narodowościowymi w Guberni Generalnej należy uwzględniać ich odrębności etniczne”. Cyt. za: Piotrowski 1957, s. 141.

${ }^{31}$ Warto odnotować, że w ostatnich dwóch punktach uwagi Plügla były zbieżne z wytycznymi B. Piłsudskiego zawartymi w jego projekcie z 1913 roku, co może sugerować, że to właśnie projekt Piłsudskiego został przedstawiony Plüglowi przez J. Zborowskiego. Por. Piłsudski 1914-1921, s. 147-188. 
Herman Mentz swe pierwsze sprawozdanie nt. Bericht über den Stand des TatraMuseums in Zakopane (Raport z obecnego stanu Muzeum Tatrzańskiego w Zakopanem) z datą 23 kwietnia 1941 roku przesłał na ręce wspomnianego wyżej referenta dra R. Albrechta ${ }^{32}$. Warto dodać, że w liście przewodnim, do którego dołączył raport odnotował, że „zajmowanie się muzeum sprawiało” mu dużą przyjemnośćs3.

W samym sprawozdaniu Mentz dokonał przeglądu poszczególnych części ekspozycji począwszy od działu ludoznawczego z budownictwem, sztuką snycerską, odzieżą, pasterstwem, aż do sektora krajoznawczo-przyrodniczego. Omawiając kolejne bloki tematyczne skoncentrował się przede wszystkim na kwestiach technicznych. Proponował między innymi wprowadzenie nowych witryn, zmianę ustawienia gablot, a także redukcję prezentowanych obiektów. Krytycznie ocenił np. rozmieszczenie obrazów na szkle, które jego zdaniem kontrastowały z całością ekspozycji i zajmowały zbyt wiele miejsca. Szereg zastrzeżeń budził też u Mentza sposób prezentacji ubioru: „Odzież wisi bez żadnego zabezpieczenia, jest mocno zabrudzona i grozi jej zniszczenie”. Jako interesującą ocenił ekspozycję poświęconą pasterstwu. Przechodząc do działu krajoznawczo-przyrodniczego, krótko omówił występujące tu bloki: geologiczny, flory i fauny oraz mineralogiczny. Podkreślił atrakcyjność niektórych okazów. Jako podstawowy mankament w tej części wymienił jednak brak napisów w języku niemieckim, co sprawiało, że przekaz był nieczytelny dla niemieckiego odbiorcy. Krytykował też niedbale wykonane etykiety $\mathrm{w}$ języku niemieckim umieszczone w sektorze ludoznawczym. Pozytywnie wypowiedział się natomiast Mentz na temat zbiorów bibliotecznych. W zakończeniu raportu sformułował najważniejszy postulat, dotyczący przekształcenia profilu Muzeum. Uważał on, że należy „zneutralizować położony przez Polaków nacisk na naukowy charakter muzeum” i stworzyć „muzeum dla zwiedzających”. W tym celu zaproponował wydanie niemieckiego katalogu oraz przygotowanie zestawu fotografii do prelekcji wygłaszanych w Rzeszy na temat Tatr.

Zarysowaną w pierwszym sprawozdaniu wizję Muzeum Tatrzańskiego H. Mentz doprecyzował w kolejnym dokumencie pt. Bericht zur Umgestaltung des Tatra-Museums in Zakopane (Raport dotyczacy reorganizacji Muzeum Tatrzańskiego w Zakopanem) opatrzonym datą 29 maja 1941 roku $^{34}$. Znaczną część dokumentu poświęcił omówieniu zawartości ekspozycji z propozycjami konkretnych zmian w poszczególnych działach. Wśród koniecznych zmian wymienił między innymi dokonanie korekty map Podhala, tak by uwydatnić historyczny „wkład Niemców w rozwój wschodnich terenów”. Oprócz uwag dotyczących ekspozycji, przedstawił też swoją koncepcję działalności Muzeum określając jego podstawowe funkcje. Mentz widział w tej placówce przede wszystkim skuteczny instrument $\mathrm{w}$ propagowaniu hitlerowskiej polityki etnicznej na zdobytych

\footnotetext{
${ }^{32}$ Bericht über den Stand des Tatra-Museums in Zakopane, 23 kwietnia 1941. AAN, sygn. 111/1454.

${ }^{33}$ Pismo z dn. 23 kwietnia 1941. AAN, sygn. 111/1454.

34 Bericht zur Umgestaltung des Tatra-Museums in Zakopane, 29 maja 1941. AAN, sygn. 111/ 1454.
} 
terenach. Podkreślał, że Muzeum, które służyło polskim interesom musi zostać przekształcone „w duchu narodowosocjalistycznych zasad”. W tym celu - jak wskazywał należało usunąć „wszelkie polskie naleciałości”, tak by można było włączyć Muzeum w tworzenie nowej rzeczywistości na Wschodzie: „Generalne Gubernatorstwo jest przedpolem Rzeszy Niemieckiej i zgodnie z wolą Führera ma się stopniowo wtapiać w Rzeszę". Na kulturę podhalańską patrzył więc przez pryzmat interesów Rzeszy i traktował ją jako egzotyczną ciekawostkę dla niemieckich widzów. Miał jednak wątpliwości, jakie elementy kultury górali powinny być prezentowanie. W jego opinii eksponowanie „wielkości i oryginalności” sztuki góralskiej stało w sprzeczności z założeniami polityki etnicznej Niemiec, gdyż uświadamiało góralom przynależność do polskiego narodu: „Tajna polska propaganda czyni usilne zabiegi, aby przedstawiać górali jako Polaków, a sami górale także twierdzą ponad wszelką wątpliwość, że są Polakami, że myślą i czują po polsku”. Dlatego też podkreślał, że niewskazane jest utrzymywanie w regionie muzeum, „które będzie wzmacniać ich poczucie przynależności narodowej”35.

Jak wynika z przywołanych powyżej projektów reorganizacji Muzeum Tatrzańskiego, główne uwagi i wytyczne sformułowane tak przez A. Plügla jak i H. Mentza zgodne były z ogólnymi założeniami hitlerowskiej polityki wobec Podhala. Pisane w duchu narodowosocjalistycznych zasad wykazywały jednak rozbieżności w zakresie ujmowania zdeponowanych zbiorów oraz roli i profilu działalności samej placówki. A to z kolei implikowało odmienne wizje góralszczyzny. A. Plügel opowiadając się za odrębną od polskiej grupy etnicznej koncepcją narodu góralskiego podkreślał potrzebę eksponowania specyfiki kulturowej górali. Zakładał, że w przyszłości górale wspierani przez niemieckie władze rozwijać będą swą regionalną odrębność, wpisaną jednak w strukturę etniczną Rzeszy. Dlatego zalecał, by zakopiańska placówka stała się dla górali muzeum ojczyźnianym. Ponadto widział w przyszłym Muzeum ważny ośrodek badań naukowych nad góralszczyzną i całym obszarem Karpat. Natomiast Mentz z dystansem odnosił się do idei odrębnego narodu góralskiego. Negował zasadność eksponowania oryginalności kultury ludowej Podhala, gdyż w jego przekonaniu oznaczało to propagowanie polskości. Nie popierał też rozwijania w Muzeum działalności naukowej. W jego zamyśle placówka miała przede wszystkim popularyzować walory krajobrazowe i turystyczne Tatr - ukazując piękno tej dawnej, „odzyskanej przez Rzeszę germańskiej krainy”.

\section{Dziedzictwo, ale jakie? Kilka refleksji na zakończenie.}

$\mathrm{W}$ rozważaniach zawartych $\mathrm{w}$ dwóch częściach prezentowanego artykułu, tak w powyższym szkicu, jak i tekście opublikowanym w 2018 roku, starałam się scharakteryzować wybrane praktyki muzealne stosowane w Muzeum Tatrzańskim począwszy od uroczystego otwarcia placówki w 1889 roku, aż do czasów II wojny światowej. Omawiając różne idee, koncepcje i sposoby gromadzenia oraz eksponowania zbiorów, chciałam

35 Bericht zur Umgestaltung des Tatra-Museums in Zakopane, 29 maja 1941. AAN, sygn. 111/ 1454. 
prześledzić jak na przestrzeni pierwszego półwiecza działalności tej instytucji, przebiegał proces materialnego zapisu dziedzictwa regionu, i jakie były jego związki z tradycją, nauką, pamięcią, oraz polityką. Analiza dostępnych materiałów pokazała, że w zależności od uwarunkowań politycznych, historycznych i społecznych wytwarzano tu odmienne wizje góralszczyzny, przypisując zdeponowanym zbiorom różne treści i znaczenia. Niestety zdarzało się, że muzealny kapitał traktowany był także jako narzędzie politycznej perswazji i symbolicznej przemocy.

Pierwsza ekspozycja w MT zgodnie z zainteresowaniami jej fundatorów zbudowana została na bazie okazów flory i fauny tatrzańskiej. W tak skonstruowanej wizji Tatr i Podhala zabrakło artefaktów miejscowej kultury. To góry i przyroda tatrzańska zasługiwały na uwagę. Widziano w Tatrach malowniczy zakątek byłej Rzeczypospolitej, cel turystycznych wypraw, źródło estetycznych doznań i artystycznych podniet. Te właśnie aspekty regionalnego pejzażu, owe „skarby” polskich $\operatorname{Tatr}^{36}$, uznane zostały za godne zachowania i eksponowania. Pierwotne założenia fundatorów MT zostały jednak szybko skorygowane i już w pierwszym statucie wprowadzono punkt dotyczący gromadzenia „wytworów przemysłu miejscowego" ${ }^{37}$. Mimo powyższego zapisu, kultura podhalańska pozostawała na uboczu działalności Muzeum. Zasadniczą zmianę w tym zakresie przyniósł przełom XIX i XX stulecia i rozwijający się w tym czasie w Zakopanem nurt młodopolskich zainteresowań i fascynacji góralszczyzną. Za sprawą polskich elit intelektualnych na czele ze Stanisławem Witkiewiczem miejscowa tradycja uznana za skarbnicę "prapolskich cech” wyniesiona została do rangi narodowego dziedzictwa, stając się dla wielu twórców źródłem artystycznych podniet i inspiracji ${ }^{38}$. W duchu młodopolskich fascynacji Podhalem wykreowano też patriotyczną koncepcję góralszczyzny, nakazującą widzieć w góralach archaiczny, „czysty” rdzeń polskiego narodu. Tak dowartościowana kultura podhalańska znalazła swą reprezentację także w muzealnych zasobach. Ważną rolę w tym zakresie odegrał Bronisław Piłsudski, który jednak z dystansem odnosił się do egzaltowanych uniesień entuzjastów tatrzańskich nad „pięknem duszy Górala”. Drażniła go fasadowa góralomania: „Był czas - pisał - kiedy zachwycano się zaściankowo-sentymentalnym Góralem, lecz niewiele przeprowadzono badań nad jego życiem. Dotychczasowe zaś prace etnograficzne i utwory literackie mimo całej swej wartości nie dają całkowitego obrazu życia ludu na Podhalu" ${ }^{39}$. Postulował więc B. Piłsudski kompleksowe badania etnograficzne uwzględniające szerszy kontekst społeczny, historyczny

\footnotetext{
${ }^{36}$ Takie określenie pojawia się w liście zarządu TT wystosowanym w 1875 roku do Edwarda Homolacsa. Cyt. za: Moździerz 2001 [wyd.2002], s. 88.

${ }^{37}$ Moździerz 2001 [wyd.2002], s. 92.

${ }^{38}$ Sztandarowym przykładem jest twórczość Stanisława Witkiewicza, który powołując się na prapolskie pierwiastki zakorzenione $\mathrm{w}$ tradycji podhalańskiej, spożytkował je $\mathrm{w}$ wykreowanym przez siebie stylu zakopiańskim w architekturze i sztuce użytkowej, a także w programie „moralnego odrodzenia polskiego narodu". Zob. Majda 1979, s. 114-115.

${ }^{39}$ Cyt. za: Zborowski 1976, s. 41.
} 
i polityczny. Podkreślał konieczność rejestrowania pomijanych dotąd zjawisk, jak oświata, wychodźstwo, gospodarka i ekonomia ${ }^{40}$. Koncentrując swe wysiłki wokół stworzenia w Muzeum działu ludoznawczego Piłsudski wyznaczył jednocześnie podhalańskiej kulturze ważne miejsce $\mathrm{w}$ praktykach muzealnych. ${ }^{41}$ Ponadto $\mathrm{w}$ swym planie rozwoju Muzeum uwzględnił górali jako aktywnych aktorów życia społecznego i kulturalnego. Tym samym dołączył do grona polskich intelektualistów, którzy realizując pod Tatrami swe twórcze pasje, działali jednocześnie na rzecz aktywizacji społeczno-kulturowej miejscowego środowiska. Niewątpliwie to współdziałanie „panów z tuziemcami” przyczyniło się do wzrostu samowiedzy kulturowej mieszkańców Podhala, a także rozwoju poczucia przynależności narodowej ${ }^{42}$. Na gruncie ideowym przygotowanym przez „panów z dolin" przedstawiciele rodzimej góralskiej elity powołali do życia w 1919 roku organizację regionalną o nazwie Związek Podhalan, która do dziś aktywnie działa na terenie niemalże całej polskiej góralszczyzny, współkształtując kulturowy obraz regionu ${ }^{43}$.

W okresie II wojny światowej Muzeum Tatrzańskie zostało przejęte przez hitlerowską administrację i podobnie jak cała góralszczyzna podhalańska stało się przedmiotem ideologicznych gier i eksperymentów. Jak wykazała analiza niemieckich raportów, nazistowscy funkcjonariusze usiłowali dostosować zdeponowany w Muzeum kapitał do potrzeb polityki etnicznej okupanta. A. Plügel w swej wizji przyszłego muzeum popierając ideę narodu góralskiego, starał się wykazać etniczną i kulturową odrębność górali względem polskiego narodu. $Z$ kolei H. Mentz dostrzegając silną identyfikację Podhalan z polską kulturą dążył do „oczyszczenia” miejscowej tradycji z wszelkich - jak pisał „polskich naleciałości”. I w jednym i w drugim przypadku chodziło o semantyczne przenicowanie góralszczyzny celem usunięcia $z$ niej śladów polskości. Tak przekształcony przez nazistów obraz góralszczyzny miał być jednym z argumentów uzasadniających prawo Rzeszy do okupowanych terenów Polski. Ponadto, jak wiadomo został wykorzystany w nazistowskiej akcji Goralenvolk ${ }^{44}$ zakładającej wynarodowienie górali i zantagonizowanie ludności zamieszkującej Polskę ${ }^{45}$.

Przedstawione powyżej rozważania chociaż odnoszą się do historycznych już wydarzeń, dotykają wciąż aktualnych spraw i problemów. Przykład nazistowskich

${ }^{40}$ Piłsudski 2016, s. 157.

${ }^{41}$ Co prawda zakopiańska placówka przed przybyciem B. Piłsudskiego do Zakopanego posiadała w swych zbiorach okazy podhalańskiej sztuki, niemniej był to zbiór przypadkowo zgromadzonych obiektów.

${ }^{42}$ Kolbuszewski 1981, s. 21. Zob. też Trebunia-Staszel 2014, s. 251-288.

${ }^{43}$ Aktualnie Związek Podhalan w Polsce posiada około 80 czynnych oddziałów i ognisk działających głównie na terenie polskiej góralszczyzny. Zob. http://zwiazek-podhalan.com/historia/dzialalnosc-zp/. Należy zaznaczyć, że podhalańscy regionaliści aktywnie działają także poza granicami kraju. Przykładem znamiennym jest Związek Podhalan w Północnej Ameryce (ZPPA), który w bieżącym roku (2019) roku świętuje 90. rocznicę swego powstania. Na temat historii i działalności ZPPA można przeczytać w wydawanym od 1947 roku w New Jersey periodyku „Tatrzański Orzeł/ The Tatra Eagel” 2019, T. 72, nr 2.

${ }^{44}$ Szatkowski 2012, s. 88-121.

${ }^{45}$ Madajczyk 1961, s. 48. 
eksperymentów z góralszczyzną uzmysławia na nowo problem politycznego uwikłania praktyk muzealnych i kreowanych w muzeach wizji rzeczywistości. Mimo, że czasy systemów totalitarnych w Europie należą do przeszłości, zagrożenia związane z próbami instrumentalizacji i manipulacji dobrami kultury, pamięcią i historią nie zostały usunięte. Tego typu praktyki i działania zdarzają się i dzisiaj ${ }^{46}$.Jak przestrzega Elżbieta Berendt, pojawiające się obecnie próby upolitycznienia, a także utowarowienia muzeów powinny być przedmiotem nieustannej refleksji krytycznej, gdyż tworzą niebezpieczny kontekst dla rzetelności naukowego i edukacyjnego wywodu ${ }^{47}$. Co więcej, nie pozostają też bez wpływu na społeczne przekonania i postawy - mogą budować pozytywne relacje międzyludzkie, ale także niestety wyzwalać negatywne emocje, fobie i uprzedzenia.

\section{Bibliografia}

Berendt E. 2014, Symulakrum albo "miejsce schadzki w celu bawienia się wzajemnego naukami i kunsztami” „Zbiór Wiadomości do Antropologii Muzealnej”, nr 1, s. 31-48.

Clair J. 2009, Kryzys muzeów, Wydawnictwo słowo/obraz terytoria, Gdańsk.

Folga-Januszewska D.2008, Muzeum: definicje ipojecie. Czym jestmuzeum dzisiaj? „Muzealnictwo”, nr 49, s. 200-203.

Gąsiorowski T. 2010, Podhale w planach niemieckiego okupanta, ,Biuletyn IPN”, nr 1-2 (108-109), s. $20-23$.

Gottschall L. 2015, Student wiedeńskiego Wydziatu Ludoznawstwa i aktywny cztonek NSDAP Anton Adolf Plügel, [w:] Maj M. (red), Antropologia i etnologia w czasie wojny. Działalność Sektion Rassen-und Volkstumsforschung Institut für Deutsche Ostarbeit w świetle nowych materiatów zródtowych, Wydawnictwo Uniwersytetu Jagiellońskiego, Kraków, s. 95-102.

Jamka R. 1964, Urywki z okupacyjnych wspomnień archeologa, [w:] Zarębowie M. A. (red.) Alma Mater w podziemiu, Wydawnictwo Literackie, Kraków, s. 208-221.

Kolbuszewski J. 1981, Kultura podhalañska jako składnik kultury narodowej, „Podhalanka”, r.1, nr 1/6, s. 21-24.

Kowalski K. 2013, O istocie dziedzictwa europejskiego, Międzynarodowe Centrum Kultury, Kraków.

\footnotetext{
${ }^{46}$ Wymownym przykładem w tym kontekście mogą być opisane przez francuskiego muzealnika Jean Claira polityczne kulisy utworzenia w Abu Zabi tzw. „Małego Luwru”, czy też w odniesieniu do polskiego kontekstu zawirowania wokół ekspozycji w Muzeum II Wojny Światowej. Zob. Clair 2009 oraz Żeby wystawa była polska. Rozmowa z prof. Włodzimierzem Borodziejem, historykiem Uniwersytetu Warszawskiego, „Gazeta Wyborcza” 7 listopada 2017, s. 14. Z drugiej strony, biorąc pod uwagę rozwój nowożytnego muzealnictwa w Europie z jego społeczną misją kształtowania świadomości narodowej tworzących się ówcześnie narodów, można przyjąć, że tego typu praktyki w mniejszym lub większym stopniu od początku wpisane były w charakter działalności instytucji muzealnych. Żygulski 1982, s. 48-73. Por. też. Folga-Januszewska 2008, s. 200-203.

${ }^{47}$ Berendt 2014, s. 31-48.
} 
Madajczyk Cz. 1961, Generalna Gubernia w planach hitlerowskich, Państwowe Wydawnictwo Naukowe, Warszawa.

Maj M., Trebunia-Staszel S. 2015, Dziatalność Referatu Etnologii Sekcji Rasowo-Ludoznawczej w świetle nowych materiatów źódtowych, [w:] Maj M. (red.), Antropologia i etnologia w czasie wojny. Dziatalność Sektion Rassen- und Volkstumsforschung Institut für Deutsche Ostarbeit, Krakau 1940-1944, w świetle nowych materiatów źródtowych, Wydawnictwo Uniwersytetu Jagiellońskiego, Kraków, s. 103-144.

Majda J. 1979, Góralszczyzna w twórczości Stanistawa Witkiewicza, PAN, Komitet Nauk o literaturze, Rozprawy Literackie 28, Wrocław.

Michel U. 2000, Ethnolpolitische Reorganisationsforschung am Institut für Deutsche Ostarbeit in Krakau 1941-1945, [w:] Streck B. (red.) Ethnolohie und Nationalsozialismus, Gehren, s. $149-166$.

Moździerz Z. 2001 [wyd. 2002], O początkach Muzeum Tatrzañskiego nieco inaczej, „Wierchy”, r. 67, s. $87-94$.

Piłsudski B. 1914-1921, W sprawie Muzeum Tatrzañskiego (O urządzenie dziatu ludoznawczego), „Rocznik Podhalański”, r.1, s. 147-188.

Piłsudski B. 2016, Projekt «Podhalańskiego Rocznika Naukowego», [w:] Kuczyński A. (oprac.), Kochany Wujaszku. Listy Bronistawa Pitsudskiego do Stanistawa Witkiewicza, Muzeum Tatrzańskie, Muzeum Józefa Piłsudskiego, Zakopane-Sulejówek, s. 155-161.

Piotrowski S.1957, Dziennik Hansa Franka, Wyd.II, Seria: Sprawy polskie przed Międzynarodowym Trybunatem Wojennym w Norymberdze, t. I, Warszawa.

Plügel A. 1941a, Das Rassenbild des Vorfeldes im deutschen Osten, „Das Vorfeld”, 2 Jahr., F. 6, s. $6-15$.

Plügel A. 1941b, Die podhalanischen Góralen im südlichsten Teil des Kreises Neumarkt. I Teil, "Die Burg”, Vierteljahresschrift des Instituts für Deutsche Ostarbeit Krakau, 2 Jahr., H. 3, s. 54-66.

Plügel 1942a, Die podbalanischen Góralen im südlicbsten Teil des Kreises Neumarkt. II Teil, "Die Burg”. Vierteljahresschrift des Instituts für Deutsche Ostarbeit Krakau, 3 Jahr, H. 1, s. $94-159$.

Plügel 1942b, Die podhalanischen Góralen im südlichsten Teil des Kreises Neumarkt. III Teil,"Die Burg”. Vierteljahresschrift des Instituts für Deutsche Ostarbeit Krakau, 3 Jahr, H. 2, s. $236-257$.

Rybicka A., 2002, Instytut Niemieckiej Pracy Wschodniej. Institut für Deutsche Ostarbeit. Kraków 1940-1945, DiG, Warszawa.

Szatkowski W. 2012, Goralenvolk. Historia zdrady, Kanon, Kraków.

„Tatrzański Orzeł/The Tatra Eagle”, 2019, t. 72, nr 2.

Trebunia-Staszel S. 2014, Kultura ludowa nieutracona. Oblicza wspótczesnej kultury regionalnej Podhala, [w:] Fatyga B., Michalski R. (red.), Kultura ludowa. Teorie. Praktyki. Polityki, Instytut Stosowanych Nauk Społecznych, Warszawa, s. 251-288. 
Trebunia-Staszel S. 2016, Wizja góralszczyzny w świetle niemieckich planów ekspozycyjnych w Muzeum Tatrzańskim, „Prace Etnograficzne”, t. 44, nr 4, s. 271-291.

Trebunia Staszel S. 2018, Muzeum Tatrzańskie jako laboratorium dziedzictwa. Częś I, "Journal of Urban Ethnology", nr 16, s. 217-231.

Wieczorkiewicz A. 1996, O funkcji i retoryce wypowiedzi muzealnej, „Konteksty. Polska Sztuka Ludowa”, r. 50, nr 1-2, s. 37-52.

Zborowski J. 1976, Z dziejów ludoznawstwa i muzealnictwa na Podhalu, „Rocznik Muzeum Etnograficznego w Krakowie”, t.VI, s. 35-115.

Zborowski J. 2001, Sprawozdanie Muzeum Tatrzańskiego za okres okupacji (Zakopane, 2 maja 1946), [w:] Jost H., Zakopane czasu okupacji. (Wspomnienia), Towarzystwo Muzeum Tatrzańskiego, Zakopane, s. 258-262.

Żygulski Z.1982, Muzea na świecie. Wstęp do muzealnictwa, Państwowe Wydawnictwo Naukowe, Warszawa.

Żeby wystawa byta polska. Rozmowa z prof. Włodzimierzem Borodziejem, historykiem Uniwersytetu Warszawskiego, „Gazeta Wyborcza, 7 listopada 2017, s. 14.

\section{Archiwalia}

Archiwum Uniwersytetu Jagiellońskiego: Kolekcja Sektion Rassen-und Volkstumsforschung, Institut für Deutsche Ostarbeit przekazana przez National Anthropological Archives, Smithsonian Institution w Waszyngtonie, SRV IDO, Box. 1-83.

Archiwum Akt Nowych w Warszawie (AAN): Pisma urzędowe w sprawie Muzeum Tatrzańskiego. Archiwum Akt Nowych w Warszawie. Zespół Akt Rządu Generalnego Gubernatorstwa 1939-1945. Nr zespołu 111, sygn. Akt 1454.

Archiwum Muzeum Archeologicznego w Krakowie: Kowalska-Lewicka A, Muzeum Archeologiczne PAU - czas okupacji (luźne wspomnienia). Maszynopis opatrzony datą 24 luty 2004 rok, s. 39.

\section{Źródła internetowe}

http://zwiazek-podhalan.com/historia/dzialalnosc-zp, 5.04.2018. 
